\title{
The impact of age and gender on Prep children's academic achievements
}

\section{Margot Boardman}

\section{University of Tasmania}

Within the current climate of heightened interest in the education of young children, it is essential that consideration be given to different factors which may impact, either positively or negatively, on the achievement of young learners when their academic progress in literacy and numeracy is considered. The research study reported in this paper aimed to investigate whether age and gender impacted on the academic results of five- and sixyear-old students in Tasmanian state schools. The dual-method study considered the children's development in the area of early literacy and numeracy, at the commencement of their year in Prep (following their previous year in kindergarten). Results for 884 students from the PIPS (Performance Indicators of Primary Schools) testing procedure (mandated by the Tasmanian Department of Education for all children at the start of their year in Prep) were used to inform this study. Quantitative results revealed that children's age had a significant impact on the results they receive in PIPS at the commencement of Prep. Younger children (aged 5.00-5.03 years at the time of the test) within the Prep class cohort were found to be performing at significantly lower levels of academic achievement than their peers who were six to 11 months older in the areas of maths, reading and phonics. Likewise, girls achieved statistically higher results in reading and in the PIPS total scores, when compared to the scores of boys. This study provides key evidence that there are children who, because of their age or gender, are achieving lower test scores on PIPS. These children and their needs in literacy and numeracy must be more fully understood and acted upon.

Keywords: early literacy; early numeracy; impact of age and gender on student attainment

\section{Background to the study}


Over the past decade there has been a renewed interest in the cognitive development of young children. In Tasmania, this interest has resulted in the introduction of compulsory assessment procedures for children in kindergarten and Prep. Children are checked for learning readiness during kindergarten (when they are four to five years old), with all Tasmanian attendees undertaking the Kindergarten Development Check (Department of Education, 2003). During the following year, Prep children (traditionally aged between 5.0 and 6.0 years on the first of January of the year they commence Prep) are assessed via a computerbased program called Performance Indicators for Primary Schools (PIPS), in the areas of early reading, phonics and mathematics.

Simultaneously, over the past decade there has been a move towards full day attendance for kindergarten children in many Tasmanian urban schools. Much research has been undertaken in the United States of America regarding the advisability and benefits of all-day attendance for kindergarten children. Some writers (da Costa \& Bell, 2001; Gullo, 2000; Cryan, Sheehan, Weichel \& BandyHedden, 1992; Housden \& Kam, 1992) have seen this change in attendance as being supportive of the academic preparation of young children. In addition, supporters of full-day kindergarten point to the current research in the neurosciences, which highlights the importance of 'a well-planned and wellexecuted pedagogy' in the first years of a child's life, with full-day kindergartens being seen as raising 'the threshold for student achievement' and producing 'academically stronger students' (Tantum, 1999, p. 24-26). However, Elicker and Mathur (1997) assert that this move to full-day kindergarten has resulted in kindergarten education becoming more academic and skills-oriented, with 'play and socialization [taking] a back seat to preparation for an increasingly rigorous first grade curriculum' (p. 460).

More recently, Tasmanian-based research into different modes of kindergarten attendance for four- and five-year-olds has shown that full-days of kindergarten were preferred by more than half of the parents involved in the study as they believed full-day attendance assisted children to become ready for later education (Boardman \& Kelly, 2002). In contrast, the majority of Tasmanian kindergarten teachers expressed concern that some teachers were providing inappropriate learning for kindergarten children during full-day sessions, while they also believed 
a number of children find being away from home for a whole day to be most stressful (Boardman, 2001).

In this educational context, ascertaining the impact of curriculum approaches on the young learner was seen to be an important direction for research within the current Tasmanian setting. The researcher was aware of 'great variability in the growth and development of four- and five-year-olds' (Seefeldt \& Wasik, 2002, p. 58). However, it was considered important to investigate how different age groups of the kindergarten cohort were coping with the changed provisions in kindergarten. Although it was acknowledged that 'a child's age does not necessarily predict the competencies of the child' (Seefeldt \& Wasik, 2002, p.58), discussions with kindergarten teachers around Tasmania had highlighted concerns regarding how the youngest (especially male) members of the kindergarten cohort were coping with the increased academic pressure of changed learning programs. To this end a research project was undertaken to compare and contrast the PIPS literacy and numeracy results of young children at the start of their year in Prep, following their year in kindergarten, using the child's age and gender as variables (Boardman, 2005).

\section{Method}

During the first month of the new school year, all state school Prep classes in Tasmania undertake the PIPS formalised testing procedure to gather baseline data for all Prep attendees in the areas of literacy and numeracy. Such results were seen to provide a reliable and statistically sound data set for use in this study. Subsequently, following the completion of the PIPS testing procedure, Prep teachers from $38(n=38)$ primary and district high schools in three education districts, seen to be a representative sample of the Prep cohort across the state, agreed to participate in this study. Teachers were asked to complete a set questionnaire designed to provide relevant information from the PIPS results for each child in the class, as well as demographic information for each child, including his/her age and gender. This factual questionnaire format was appropriate for this phase of the study, as it allowed a wide variety of information to be gathered.

Analysis of the questionnaire data, involving records for 884 Prep children, was a complex process, which involved "progressively summarising and "distilling" the 
data to arrive in the end at substantive conclusions' (Punch, 2003, p. 65). Each set of information from the questionnaires was then entered into an Excel spreadsheet, where it was summarised and reduced to allow the distribution of the variables to be shown. Following this, the data was imported into the statistical program Statview, which enabled descriptive and inferential analysis to be undertaken,enabling correlation between variables to be expressed in statistical amounts (Thomas, 2003, p. 50). One-way analysis of variance (ANOVA) was used to test for statistically significant differences among different groups of children's scores, in respect to age and gender. This procedure meant that a higher level of confidence could be held in results that revealed a significance level of $p<.05$, as the results were less likely to have occurred by chance (Burns, 2000).

Later in the project a focus group interview process, involving self-nominated Prep teachers $(n=15)$, was undertaken to discuss trends and issues arising from the questionnaire phase of the study (Burns, 2000). Three focus-group interviews, in different areas of Tasmania, were undertaken to allow the researcher to ask specific questions of each group of interviewees. During this process opportunities were also available for exploration, expansion and discussion of issues concerning the impact of children's age and gender on their PIPS results. The interviews were audio-taped, then transcribed into Word documents where data was coded using the constant comparative method (Merriam, 1998) allowing one segment of data to be compared with another to determine similarities and differences.

\section{Results}

\section{Investigating the impact of age on children's PIPS results}

Children in this study were aged between 6.03 months and 5.00 months on 1 January 2004. Their ages in years and months have been calculated accordingly for analysis' purposes in this study. Groupings of children were made in regular intervals, for example 5.00 to 5.03 years. Analysis of the raw scores from the PIPS results according to age groupings (see Table 1 ) indicated that the children aged 5.07-5.09 achieved the highest scores in maths (36.05), while the children aged 5.10-6.00 scored the highest results in reading (50.76) and the oldest group, those aged 6.01-6.03, scored the highest scores in phonics (13.06). The group of children aged 5.00-5.03 scored the lowest results in all three aspects of PIPS 
(maths=32.14; reading $=42.74$; phonics $=10.83$ ) when compared to other age groups. Further, all children aged between 5.00-5.06 scored lower results in maths and reading than the overall total score for these two areas. It should be noted that in this study the small group $(n=17)$ aged 6.01-6.03 years comprised children who were repeating Prep for a second year, usually for health, academic and/or social reasons, and therefore no significant results would be expected from this group.

Table 1. Comparison of PIPS scores considering children's age

\begin{tabular}{|c|c|c|c|c|}
\hline Age & $\begin{array}{l}\text { Maths } \\
\text { (mean } \\
\text { score) }\end{array}$ & $\begin{array}{l}\text { Reading } \\
\text { (mean } \\
\text { score) }\end{array}$ & $\begin{array}{l}\text { Phonics } \\
\text { (mean } \\
\text { score) }\end{array}$ & $\begin{array}{l}\text { Total } \\
\text { (mean } \\
\text { scores) }\end{array}$ \\
\hline $\begin{array}{l}5.00-5.03 \\
(n=256)\end{array}$ & 32.14 & 42.74 & 10.83 & 83.37 \\
\hline $\begin{array}{l}5.04-5.06 \\
(n=231)\end{array}$ & 33.55 & 46.09 & 12.66 & 90.71 \\
\hline $\begin{array}{l}5.07-5.09 \\
(n=190)\end{array}$ & 36.05 & 50.10 & 12.45 & 94.97 \\
\hline $\begin{array}{l}5.10-6.00 \\
(n=169)\end{array}$ & 35.89 & 50.76 & 12.78 & 94.89 \\
\hline $\begin{array}{l}6.01-6.03 \\
(n=17)\end{array}$ & 34.18 & 46.17 & 13.06 & 93.41 \\
\hline $\begin{array}{l}\text { Total } \\
(\mathrm{n}=863)\end{array}$ & 34.14 & 46.88 & 12.10 & 90.35 \\
\hline
\end{tabular}

${ }^{*}$ Results for totals may not agree with results for individual cells because of missing values for split variables

Statistical analysis of the data revealed a number of significant differences (see Table 3 in the Appendix). A significant result (of $p=.002$ ) was revealed between the children aged 5.00-5.03 and 5.07-5.09 when their maths scores were compared. Further significant results in maths $(p=.006)$ and also in reading $(p=.050)$ were 
found when the results for children aged 5.00-5.03 were compared with the results of the 5.10-6.00-year-olds. One statistically significant result of $p=.046$ was returned in the phonics' results when scores from children aged 5.00-5.03 were compared to those from children aged 5.10-6.00. When the total scores across the maths, reading and phonics were analysed there was one area of significance. This result of $p=.045$ was recorded between children aged 5.00-5.03 and those aged 5.07-5.09. It is evident that the younger members of the cohort, children aged 5.00-5.03, were not performing at the same level of proficiency as children aged 5.07 and older.

\section{Investigating the impact of gender on children's PIPS results}

Analysis of the raw scores from the PIPS results, considering the aspect of gender, revealed some interesting results: girls scoring higher in all aspects of the PIPS results, with the highest mean score difference (4.55) being in reading.

Table 2. Comparison of scores considering gender of children

\begin{tabular}{|l|l|l|l|}
\hline $\begin{array}{l}\text { Population } \\
\text { according to } \\
\text { gender }\end{array}$ & $\begin{array}{l}\text { Maths } \\
\text { (mean } \\
\text { score) }\end{array}$ & $\begin{array}{l}\text { Reading } \\
\text { (mean } \\
\text { score) }\end{array}$ & $\begin{array}{l}\text { Phonics } \\
\text { (mean } \\
\text { score) }\end{array}$ \\
\hline Male $(\mathrm{n}=462)$ & 33.73 & 44.73 & 11.89 \\
\hline $\begin{array}{l}\text { Female } \\
(\mathrm{n}=421)\end{array}$ & 34.64 & 49.28 & 12.31 \\
\hline Total $(\mathrm{n}=883)$ & 34.17 & 46.95 & 12.09 \\
\hline
\end{tabular}

* Results for totals may not agree with results for individual cells because of missing values for split variables

Statistical analysis according to gender (see Table 4 in Appendix) showed that the girls' result in reading was significant at $p=.010$. A similar result was found when the total results of the maths, phonics and reading were considered, with a significant difference between the girls' and boys' results of $p=.021$.

\section{Discussion}




\section{Children's age does make a difference in the results they achieve in the PIPS} testing

This study clearly demonstrates that children's age had a significant impact on their results in the PIPS testing procedure at the commencement of Prep. These results validate that younger children within a Prep class cohort are performing at significantly lower levels of academic achievement than their peers who are six to 11 months older. When participants in the focus group interviews were asked why they believed these significant results had occurred, one respondent stated:

I would think it is developmental. Six months at the age of a five-year-old ... what fraction is that? So there are a lot of experiences that kids have in those times-lots that I think impact on their learning.

Another teacher commented in a similar vein, stating:

Well, when we talk about the huge advances happening every day in Prep, it has to impact. It is a developmental thing.

When more specific discussion was undertaken with teachers in the interviews regarding why young children, aged between $5.07-5.09$ and $5.10-6.00$ years, were operating at significantly higher levels in maths than their peers aged 5.00-5.03 years, the responding teachers made the following comments:

I do find that PIPS test difficult with the maths especially when they show the dots and they say-15 add on 5.

That is really targeting your upper kids!

Some of those [children] will get to that by the end of the year.

I know. It is just a funny way of putting it!

These comments are interesting, and reference to the writings of Seefeldt and Wasik (2002) remind teachers that 'for five year olds, conservation of number is developing and is generally solidified by the time children turn six years of age' ( $p$. 243). If this is the case, then any mathematical tasks that require conservation of number, which underpin complex maths concepts, may well be too hard for younger five-year-olds and this could explain why these statistically significant 
PIPS results in respect of younger children's. Extra support for this hypothesis is provided through the following comment from one of the interview participants regarding what teachers expect from young learners when they commence Prep:

So you have an expectation that these children would know how to sit down on a mat and have a conversation with you about counting and things like that and they have no idea what you are talking about. They don't even know what numbers are.

If there are children in the class who fail to understand such basic mathematical concepts, then it has to be queried whether these were the youngest members of that class cohort. If so, this could well add evidence to the hypothesis that some younger children are being asked to complete tasks outside their level of developmental competence.

This argument could also be applied to this trend which continued into the literacy results from PIPS. Indeed, the 5.00-5.03-year-olds children's scores in phonics were statistically significant when compared to their peers aged 5.04-5.06 and 5.10-6.00. These same youngest members of the Prep cohort also had a near significant result in reading when their scores were compared to 5.10-6.00-yearold children's scores. One teacher commented that in her class the younger boys were of greatest concern:

There are two of the youngest boys in my class who haven't turned 6 yet, and are possible repeats into Prep next year because of poor academic performance and ... and maturity.

The researcher asked for clarification of these children's age: 'OK, so we are talking these two who are late October and early November [birthdays]?' and the respondent agreed.

The results of these younger Prep children are important to note, as it is apparent that they are not operating at the same academic level as their older peers in Prep. It is contended that many of these younger children require a less academic focus than their older peers. They need time to develop foundational knowledge, skills and understanding through practical hands-on learning activities, founded on a play-based program, which will act as a stepping stone for their future more formal 
studies. It is essential to heed the writing of Katz (1999) who warns that pressurising young learners into formalised and didactic teaching practices too soon can have a negative impact, instead of a positive impact, on children's learning outcomes. The implications of these findings are not only important information for kindergarten teachers but are also crucial evidence for Prep teachers, who are being asked constantly to raise the literacy and numeracy outcomes of the Prep children in their class. No longer is it necessary for Prep teachers to try to justify why children with birthdays in November and December are not making the same progress as other children. The fundamental issue is that these younger children are not ready to undertake more formal studies, as was mentioned by a number of parents and teachers in Boardman's (2001) and Boardman \& Kelly's (2003) previous studies. This study provides key evidence that there are children who are operating at a different level within their literacy and numeracy work (because of their age). These children need to be catered for, and their abilities need to be more fully understood.

\section{Gender does make a difference in the PIPS scores for young children in Prep}

The second important finding of this study was that gender plays a significant part in some results achieved by Prep children in their PIPS tests. There were clear results showing that girls attained higher, statistically significant results in reading and in their total scores when compared to their male counterparts. This is not unexpected, as many previous studies have shown that females attain higher results in literacy in the early years of education. Teachers in the focus group interviews discussed this issue and provided some excellent insights into the different literacy behaviours of young girls and boys.

I suppose the boys are more active than the girls, so the boys like to do more hands-on things like the construction and things like that, and the girls would rather sit and read. That sounds like a stereotype, doesn't it?

The researcher replied:

It might be, but the bottom line is-and I suppose the thing is-is it about a developmental difference or is it...?

Another teacher interjected: 
Looking ... in my room now, the girls have more defined fine motor skills and things like that, and the boys are still having trouble with pencils and scissors and things like that. Girls sit down and read a book where the boys will go over and play with the cars or something like that!

Further, this dialogue from another interview group of teachers adds to this viewpoint:

I think if the kids have free time at all in my room, I know ... the boys will go straight to the box. The girls will get out their pad and start writing.

And drawing and so ... those sort of results [PIPS scores] ... They write down their small groups that they work with in the morning-off the walland start writing down which kids they think they are going to invite to their birthday party next year.

Another teacher also commented that often girls engage in role-play reading in the class and so are practising the skills of reading. At these times, she observed, boys sometimes join in, but only as viewers. It is evident and important to note that girls are often more interested in early text-based learning tasks than are boys, who prefer more practical exploration requiring involvement of large motor skills and active participation. Nevertheless, one teacher in the interviews provided some guidance regarding early literacy opportunities for young boys when she commented:

[You should] probably keep books in your room and read books that are targeted to boys-like maybe a book about football or this person is playing soccer and stuff like that, because then it gets them more interested.

Could this teacher have highlighted a crucial issue regarding the early literacy education of young boys? Recently, the researcher has observed that there is a greater variety of newly published simple non-fiction texts coming onto the market, which could serve to cover this deficit in early literature. It could be contended that many boys need different texts to motivate them to become involved in literacy practices, and perhaps this may prove to make a difference in the PIPS results for boys. 
Finally, teachers need to be aware of the importance of providing meaningful learning experiences for both genders. Inappropriate provisions can disenfranchise children at the crucial beginning stage of their schooling, which in turn leads to children displaying behaviours which are deemed as problematic by teachers and others. Within the current educational climate, where pressure is being placed upon teachers to focus on more formalised procedures, with set outcomes to be achieved in early literacy and numeracy, there is a real chance that a number of boys are experiencing feelings of failure early in their schooling. Indeed, Feinstein (2000) has indicated that boys with conduct disorders are much more likely to experience unemployment in their later lives. Further, parents of kindergarten boys (Boardman \& Kelly, 2003) reflected on the immaturity of boys born in the last months of the year, October-December, and their inability to cope with formal learning structures. These boys could well be those highlighted previously as achieving lower PIPS results than their older peers in kindergarten, and indeed could be potential candidates for unemployment when leaving school.

\section{Conclusion}

This is an important study, as it provides evidence from current Tasmanian educational data which has recorded some highly significant results for young children at the commencement of their compulsory Prep year. Key directions from this study can be used to inform future educational programs and to ensure that the quality of early years' provisions is enhanced in the forthcoming years. The findings demonstrate that younger children attained significantly lower results in their PIPS test than their older peers, and is therefore a crucial discovery. It clearly substantiates that younger children, especially those with birthdays in October, November and December, have different learning needs than many of their older peers in Prep, and it is strongly contended that play should be the way these younger children work and learn. This result could also be extrapolated to kindergarten, as once again these younger members of the class may well require a substantially different learning provision than their older counterparts.

With respect to the impact of gender on young children's learning at the commencement of Prep, this study has confirmed that girls are performing at a higher level in academic pursuits than are their male counterparts. Indeed, female students were found to be performing at statistically higher levels in reading and in 
the PIPS scores overall. Could it be that the boys are finding the testing and more formalised approach to learning being undertaken by many early years' teachers to be inappropriate? For, as Essa (2003) points out, by exposing young children to inappropriate tasks for which they are not developmentally ready, the learning experiences become meaningless and have little relevance. Boys require a curriculum tailored to their developmental needs. They are motivated by practical learning experiences and, as revealed in this paper, they voluntarily seek out these play-based, hands-on experiences within the classroom. Greater teacher understanding of learning in play-based experiences could well assist the young males in the early years of education and enhance their prospects for employment in the future (Feinstein, 2000). However, this will require a complete mind-shift by many Prep teachers as they learn more about children's conceptual and academic development within play-based contexts, giving them greater insight into children who do not thrive on hand-written, paper-based experiences.

\section{References}

Boardman, M. J. (2001). Kindergarten: Full-day or half-day? Investigating Tasmanian kindergarten teachers' perceptions. Unpublished research pamphlet for participants in the study and Department of Education personnel.

Boardman, M. J., \& Kelly, M. N. (2002). Kindergarten: Full-day or half-day? Tasmanian parents' views in the debate. Unpublished research pamphlet for participants in the study and Department of Education personnel.

Boardman, M. J. (2005). Full-days at kindergarten? Half-days at kindergarten? Educational implications for kindergarten children. Unpublished research report and pamphlet for the Tasmanian educational community.

Burns, R. (2000). Introduction to research methods (4th edn). Melbourne: Longman.

Cryan, J., Sheehan, R., Weichel, J., \& Bandy-Hedden, I. G. (1992). Success outcomes of full-day kindergarten: More positive behaviour and increased achievement in the years after. Early Childhood Research Quarterly, 7(2), 187203. 
da Costa, J. L., \& Bell, S. (2001). A comparison of the literacy effects of full-day vs half-day kindergarten. ERIC Document Delivery (ED 451 938).

Department of Education (2003). Kindergarten development check. Hobart: Author.

Elicker, J., \& Mathur, S. (1997). What do they do all day? Comprehensive evaluation of a full-day kindergarten. Early Childhood Research Quarterly, 12(4), 459-480.

Essa, E. L. (2003). Introduction to early childhood education (4th edn). Clifton Park, NY: Thomson Delmar Learning.

Feinstein, L. (2000). The relative economic importance of academic, psychological and behavioural attributes developed in childhood (discussion paper 443). London: Centre for Economic Performance, University of London.

Gullo, D. F. (2000). The long-term educational effects of half-day v full-day kindergarten. Early Childhood Development and Care, 160(xx), 17-24.

Housden, T., \& Kam, R. (1992). Full-day kindergarten: A summary of research. Carmichael, CA: San Juan School District (ED 345 868).

Katz, L. (1999). Another look at what young children should be learning. ERIC Digest (ED 430 735).

Merriam, S. B. (1998). Qualitative research and case study applications in education (rev. edn). San Francisco: Jossey-Bass.

Punch, K. F. (2003). Survey research. London: Sage.

Seefeldt, C., \& Wasik, B. (2002). Kindergarten: Fours and fives go to school. Saddle River, NJ: Merrill Prentice Hall.

Tantum, D. S. (1999). Is more better? Measuring the effects of full-day kindergarten. Popular Measurement, 2(1), 24-26.

Thomas, R. M. (2003). Blending qualitative and quantitative research methods in theses and dissertations. Thousand Oaks, CA: Corwin Press. 


\section{Appendix}

Table 3. Statistical results of PIPS scores considering children's age

\begin{tabular}{|l|l|l|l|l|}
\hline Age & $\begin{array}{l}\text { Total Mean } \\
\text { Difference } \\
\text { and }\end{array}$ & $\begin{array}{l}\text { Maths Mean } \\
\text { Difference } \\
\text { and }\end{array}$ & $\begin{array}{l}\text { Reading } \\
\text { Mean } \\
\text { Difference } \\
\text { and }\end{array}$ & $\begin{array}{l}\text { Phonics } \\
\text { Mean } \\
\text { Difference } \\
\text { and }\end{array}$ \\
\hline $\mathbf{p}$ value & $p$ value & $p$ value \\
\hline $\mathbf{5 . 0 0 - 5 . 0 3 , - 5 . 0 6}$ & -7.35 & -1.42 & -3.35 & -1.83 \\
$\mathbf{5 . 0 0 - 5 . 0 3 ,}$ & $(p=.360)$ & $(p=.643)$ & $(p=.736)$ & $(p=.035)$ \\
$\mathbf{5 . 0 7 - 5 . 0 9}$ & -11.61 & -3.92 & -7.36 & -1.62 \\
$\mathbf{5 . 0 0 - 5 . 0 3 ,}$ & $(p=.045)$ & $(p=.002)$ & $(p=.074)$ & $(p=.127)$ \\
$\mathbf{5 . 1 0 - 6 . 0 0}$ & -11.53 & -3.75 & -8.02 & -1.95 \\
$\mathbf{5 . 0 0 - 5 . 0 3 ,}$ & $(p=.062)$ & $(p=.006)$ & $(p=.050)$ & $(p=.046)$ \\
$\mathbf{6 . 0 1 - 6 . 0 3}$ & -10.04 & -2.04 & -3.43 & -2.23 \\
$\mathbf{5 . 0 4 - 5 . 0 6 ,}$ & $(p=.899)$ & $(p=.952)$ & $(p=.991)$ & $(p=.725)$ \\
$\mathbf{5 . 0 7 - 5 . 0 9}$ & -4.26 & -2.50 & -4.01 & .22 \\
$\mathbf{5 . 0 4 - 5 . 0 6 ,}$ & $(p=.868)$ & $(p=.157)$ & $(p=.655)$ & $(p=.998)$ \\
$\mathbf{5 . 1 0 - 6 . 0 0}$ & -4.19 & -2.33 & -4.67 & -.12 \\
$\mathbf{5 . 0 4 - 5 . 0 6 ,}$ & $(p=.888)$ & $(p=.249)$ & $(p=.544)$ & $(p=.999)$ \\
$\mathbf{6 . 0 1 - 6 . 0 3}$ & -2.70 & -.62 & -.084 & -.39 \\
$\mathbf{5 . 0 7 - 5 . 0 9 ,}$ & $(p=.999)$ & $(p=.999)$ & $(p=>.999)$ & $(p=.999)$ \\
$\mathbf{5 . 1 0 - 6 . 0 0}$ & .74 & .17 & -.66 & -.34 \\
$(p=>.999)$ & $(p=-.999)$ & $(p=.999)$ & $(p=.993)$ \\
\hline
\end{tabular}




\begin{tabular}{|l|l|l|l|l|}
$\mathbf{5 . 0 7 - 5 . 0 9 ,}$ & 1.56 & 1.88 & 3.93 & -.61 \\
$\mathbf{6 . 0 1 - 6 . 0 3}$ & $(p=>.999)$ & $(p=.966)$ & $(p=.986)$ & $(p=.997)$ \\
$5.10-6.00$, & 1.49 & 1.17 & 4.58 & -.28 \\
$6.01-6.03$ & $(p=>.999)$ & $(p=.976)$ & $(p=.975)$ & $(p=.999)$ \\
\hline
\end{tabular}

Table 4. Statistical analysis of PIPS scores considering gender of children

\begin{tabular}{|l|l|l|}
\hline $\begin{array}{l}\text { Mean score } \\
\text { difference }\end{array}$ & $\begin{array}{l}\text { Female, } \\
\text { male }\end{array}$ & $\boldsymbol{p}$ value \\
\hline Maths & .91 & .173 \\
Reading & 4.55 & .010 \\
Total & .414 & .328 \\
\hline
\end{tabular}

